\title{
Prevalence of Postharvest Diseases of Mandarin Fruit in California
}

\author{
S. Saito and C. L. Xiao, ${ }^{\dagger}$ USDA-Agricultural Research Service, San Joaquin Valley Agricultural Sciences Center, Parlier, CA 93648
}

Accepted for publication 29 September 2017.

\begin{abstract}
In recent years, storing mandarin fruit in cold facilities has become a common practice to retain fruit quality and expand the marketing window, but postharvest diseases can limit the storage period for the fruit. To identify major postharvest diseases affecting mandarins, decayed fruit were collected from 20 and 46 grower lots in 2015 and 2016, respectively, either at presorting or after cold storage. Fungal isolation and identification were attempted for all decayed fruit. Alternaria rot caused by Alternaria spp. was most prevalent on nonstored fruit collected at presorting, accounting for $53.5 \%$ and $83.1 \%$ in 2015 and 2016 , respectively. On stored fruit collected after cold storage, green mold caused by

Penicillium digitatum (36.3\%) was most prevalent followed by Mucor rot caused by Mucor piriformis $(27.7 \%)$ and blue mold caused by P. italicum $(23.3 \%)$ in 2015 , while gray mold caused by Botrytis cinerea $(29.7 \%)$ was most prevalent followed by Mucor rot $(27.1 \%)$ and sour rot caused by Geotrichum citri-aurantii (18.7\%) in 2016. Our results indicate that gray mold and Mucor rot are two emerging postharvest diseases of mandarin fruit in California and that postharvest disease-control programs for mandarin fruit should target not only common postharvest diseases such as green mold, blue mold, and sour rot, but also emerging diseases Mucor rot and gray mold.
\end{abstract}

California is the leading producer of fresh-market citrus in the United States, accounting for about $83 \%$ of the production in 20152016 (USDA-NASS). Among various types of citrus produced in the region, mandarin fruit production underwent a noticeable change in recent years (Webber et al. 2014). Consumption of and demand for mandarin fruit have been increasing during the recent decades, while those of oranges have been decreasing consistently (Ladaniya 2008). In California, the total acreage of orange groves decreased from 75,737 to 60,982 ha from 2004 to 2016 , while that of mandarins tripled from 7,492 to 23,853 ha during the same period, with a production value in $2015-2016$ exceeding $\$ 630$ million (USDA-NASS).

After harvest, mandarin fruit are commonly packed and shipped directly to the market. As the acreage and volume of harvested fruit of mandarin continue to increase, storing mandarin fruit in cold facilities has recently become a common practice to retain fruit quality and expand the marketing window. After harvest and presorting, mandarin fruit may be stored at 4 to $8^{\circ} \mathrm{C}$ for up to several weeks prior to packing and shipping to the market (Arpaia et al. 2014). However, extended storage increases the risk of postharvest disease development. Postharvest fruit rot diseases can limit the storage period of the fruit and cause significant economic losses if left uncontrolled.

Postharvest fruit rots caused by various fungal pathogens cause the most significant economic losses to the citrus industry during degreening, storage, transportation, and marketing (Akhtar et al. 2013; Smilanick et al. 2006). Green mold caused by Penicillium digitatum (Per.:Fr), blue mold caused by P. italicum (Wehmer), and sour rot

${ }^{\dagger}$ Corresponding author: Chang-Lin Xiao; E-mail: Chang-Lin.Xiao@ars.usda.gov

Mention of trade names or commercial products in this article is solely for the purpose of providing specific information and does not imply recommendations or endorsement by the U.S. Department of Agriculture. USDA is an equal opportunity provider and employer.

This article is in the public domain and not copyrightable. It may be freely reprinted with customary crediting of the source. The American Phytopathological Society, 2017. caused by Geotrichum citri-aurantii (Ferraris) are generally considered the most common postharvest diseases in citrus worldwide (Akhtar et al. 2013; Bhattarai et al. 2013; McKay et al. 2012; Smilanick et al. 2006, 2008). However, the occurrence of postharvest fruit rots of citrus can be affected by many factors such as citrus types, growing conditions in the field, and postharvest storage and handling practices (Arpaia et al. 2014; Smilanick et al. 2008; Snowdon 1990). Currently, little is known about postharvest diseases affecting mandarin fruit in cold storage for an extended period of time.

In 2013, some citrus packinghouses in the Central Valley of California, which is a primary region for mandarin production, reported to the authors that they had experienced in recent years an unknown postharvest disease on mandarin fruit stored at low temperatures for an extended period of time. This led us to initiate a postharvest survey for this unknown disease at packinghouses during the 2014-2015 harvest season. We found that the unknown disease was Mucor rot caused primarily by Mucor piriformis and reported for the first time this disease on citrus in California (Saito et al. 2016). In conjunction with this survey, we also expanded the survey for all postharvest diseases affecting stored mandarin fruit for two harvest seasons. In the present paper, we report the prevalence of all major postharvest diseases on mandarin fruit from the surveys conducted during 2014-2015 and 2015-2016 harvest seasons. It is common that multiple postharvest diseases may affect mandarin fruit during storage. Understanding major postharvest diseases affecting mandarin fruit during storage would help in identifying targets for disease control and thus in developing relevant control measures to reduce losses resulting from postharvest diseases.

\section{Surveys for Postharvest Diseases}

Decayed mandarin fruit were collected from three packinghouses in the Central Valley of California from 20 January to 21 April in 2015 and from 18 January to 13 April in 2016. The three packinghouses were located within a $60-\mathrm{km}$ radius in the Valley. Sampling was done weekly from one of the three packinghouses. At each sampling time, approximately 30 to 60 decayed fruit from each 
grower lot were collected. In this study, each grower lot represented fruit harvested from one grove, and two types of fruit, nonstored fruit and stored fruit, were collected. Nonstored fruit were subjected to presorting shortly after harvest (0 to 2 days). Presorting is a process to grade the fruit by size and eliminate small fruit and defects before the fruit are placed in cold storage. Stored fruit were presorted and stored at 4 to $5^{\circ} \mathrm{C}$ for up to several weeks after harvest. Nonstored fruit were collected mainly at the beginning of the mandarin harvest seasons, and stored fruit were collected progressively as the season advanced. Decayed fruit were transported to the laboratory, and fungal isolation as described below was performed on the same day they were collected. Color and texture (soft, firm, or watery) of the decayed areas and site of the infection were also recorded. All decayed fruit were photographed before fungal isolation in order to associate fungal pathogens with the disease symptoms they incited.

\section{Fungal Isolation and Identification}

Identification of fungal pathogens was made initially based on disease symptoms on the rind of decayed fruit, and on morphology of fungi under a microscope if sporulation or fruiting bodies of the pathogens were present on the fruit. Isolations of causal agent(s) were attempted for decayed fruit following the procedure of Kim and Xiao (2008). Briefly, all decayed fruit were surface-disinfested by spraying them with $70 \%$ ethanol and dried in a fume hood. Small fragments of the rind were excised using a sterile scalpel from the margin of the decayed and healthy tissue and transferred onto water agar. The isolation plates were incubated at $24^{\circ} \mathrm{C}$ for 5 to 7 days, allowing fungal pathogens to grow. Mycelia actively growing on the edge of the colonies on the water agar were transferred onto potato dextrose agar (PDA). The PDA plates were then incubated at $24^{\circ} \mathrm{C}$ for another 4 to 5 days. Morphological characters of fungal colony growing on PDA were observed under a microscope to identify the fungi to the genus level. Glass slides of the fungal pathogens were made, when necessary, to observe their fruiting bodies, shape of conidia, or other fungal organs. Initial identification of isolates of putative Alternaria spp., Penicillium spp., Geotrichum spp., Botrytis spp., and Mucor spp. to the genus level was based on the descriptions of respective identification manuals and articles (Barnett and Hunter, 1998; Samson and Pitt, 2000; Schipper, 1973, 1975, 1976, 1978; Simmons 2007). Fungi that were not identified based on morphological characteristics were subjected to genetic analysis as described below.

\section{DNA Extraction, PCR Amplification and Sequencing}

To identify unknown fungi recovered from diseased fruit and to confirm their initial identification based on morphological characteristics, internal transcribed spacer (ITS) of the fungi were sequenced. All unknown fungal isolates and two to five morphologically identified isolates arbitrarily chosen each month were used in this analysis. Genomic DNA was extracted from fungal mycelium grown on PDA using DNeasy Mini Spin Columns (Qiagen, Valencia, CA) according to the manufacturer's protocol. Resulting DNA solutions were used for sequencing as described below.

The ITS region was amplified using the primer pair ITS1/ITS4 (White et al. 1990). PCR was performed as described previously, with modification. Briefly, PCR amplifications were performed in a 10- $\mu$ l volume containing $10 \mathrm{ng}$ of fungal genomic DNA, $0.2 \mu \mathrm{M}$ each primer and $5.0 \mu \mathrm{l}$ of GoTaq PCR mixture (Promega, Madison, WI). PCR was carried out in a S1000 thermal cycler (Bio-Lad Life Science Research Group, Hercules, CA) with the following conditions: an initial preheating for $2 \mathrm{~min}$ at $95^{\circ} \mathrm{C}$; followed by 30 cycles of denaturation at $95^{\circ} \mathrm{C}$ for $30 \mathrm{~s}$; annealing at $55^{\circ} \mathrm{C}$ for $30 \mathrm{~s}$; extension at $72^{\circ} \mathrm{C}$ for $1 \mathrm{~min}$; and a final extension at $72^{\circ} \mathrm{C}$ for $5 \mathrm{~min}$.

PCR products were purified using the GeneJet purification kit (Thermo Fisher Scientific, Pittsburgh, PA) according to manufacturer's protocols. Purified PCR products were then directly sequenced in both directions using BigDye Terminator v3.1 Cycle Sequencing Kit in a 3130XL Genetic Analyzer (Applied Biosystems, Inc., Foster City, CA). Sequences were analyzed using BioEdit Sequence Alignment Editor v7.1.11 (Hall 1999). The ITS sequences of the isolates from mandarin fruit were subjected to the NCBI MegaBLAST search to find highly similar sequence data.

\section{Occurrence of Postharvest Diseases}

In total, 533 decayed nonstored fruit and 733 decayed stored fruit were collected in 2015 from 11 and 21 grower lots, respectively. In 2016, 390 decayed nonstored fruit and 660 decayed stored fruit were collected from 9 and 25 grower lots, respectively (Table 1). Overall, six postharvest diseases were commonly detected during the two-year survey. Those six diseases were Alternaria rot caused by Alternaria spp., blue mold caused by Penicillium italicum, green mold caused by $P$. digitatum, sour rot caused by Geotrichum citri-aurantii, gray mold caused by Botrytis cinerea, and Mucor rot caused primarily by Mucor piriformis (Table 1). Other rots were caused by other fungi or known

\begin{tabular}{|c|c|c|c|c|}
\hline \multirow[b]{3}{*}{ Diseases $^{b}$} & arvest rots cau & $\begin{array}{c}\text { TABLE } 1 \\
\text { pathogens } \\
015 \text { and } 20\end{array}$ & decayed mar & cted \\
\hline & \multicolumn{2}{|c|}{2015} & \multicolumn{2}{|c|}{2016} \\
\hline & Nonstored fruit & Stored fruit & Nonstored fruit & Stored fruit \\
\hline Alternaria rot & 53.5 & 12.1 & 83.1 & 15.3 \\
\hline Blue mold & 16.5 & 23.3 & 6.5 & 9.6 \\
\hline Gray mold & 7.7 & 11.6 & 3.5 & 29.7 \\
\hline Mucor rot & 6.2 & 27.7 & 5.6 & 27.1 \\
\hline Other rots & 16.9 & 7.8 & 10.7 & 19.7 \\
\hline
\end{tabular}

a In total, 533 and 390 nonstored decayed fruit, and 733 and 660 stored decayed fruit, were collected from 11 and 9, and 21 and 25, grower lots in 2015 and 2016 , respectively. Each grower lot represents the fruit from the same grove. The values are the mean percentages of each disease in the total decayed fruit within a grower lot. Total percentage may exceed $100 \%$ due to multiple infections on the same fruit.

${ }^{\mathrm{b}}$ Alternaria rot caused by Alternaria spp.; blue mold caused by Penicillium italicum; green mold caused by P. digitatum; Sour rot caused by Geotrichum citri-aurantii; Gray mold caused mainly by Botrytis cinerea; Mucor rot caused mainly by Mucor piriformis; and other rots caused by other fungal pathogens. 
fungal pathogens such as Aureobasidium spp., Cladosporium spp., Colletrotrichum spp., Dothiorella spp., Epicoccum spp., Fusarium spp., Penicillium spp. other than P. italicum and P. digitatum, Phoma spp., Phytophthora spp., Pleospora spp., Pyronema spp., Rhizopus spp., Sclerotinia spp., Sordaria spp., Trichoderma spp., Ulocladium spp., and yeasts. Because these individual pathogens or fungi were recovered at a low frequency and often found as secondary or tertiary pathogens without distinct disease symptoms on the fruit, species identification and pathogenicity tests of those fungi were not conducted in this study.

Figures 1 and 2 show typical symptoms of the six major postharvest diseases from the early stage to an advanced stage of symptom development. For Alternaria rot, the diseased tissue often remained firm and the lesion developed a light-brown to reddishblack discoloration on the surface of fruit. As the lesion expanded, it produced a dark gray to black mass of spores (Fig. 1 A-D). For blue mold, diseased tissue was soft, watery, and easily separated from healthy tissue. As the disease advanced, it produced blue masses of spores on the surface of the decayed area. A white fringe of mycelium surrounding the lesion was thinner than that of green mold (Fig. 1 E-H). Initial symptoms of green mold on mandarin fruit were similar to those of blue mold. After a white mycelium spread on the surface, it produced olive-green spores. The white fringe of mycelium surrounding the lesion was thicker than that of blue mold
(Fig. 1 I-L). The initial symptoms of sour rot were similar to those of blue mold and green mold. The diseased tissue was soft, watery, and exhibited light- to dark-brown discoloration on the surface. As the disease advanced, decayed tissue became digested and gelatinous and can be easily separated from healthy tissue. At an advanced stage, the fruit was completely covered with yeasty and wrinkled layers of cream-colored mycelium (Fig. $1 \mathrm{M}-\mathrm{P}$ ). For gray mold, diseased tissue was initially spongy and dark brown. As the lesion advanced, a gray mycelium started to appear on the decayed area. At an advanced stage, the fruit became soft and was covered with gray, cottony mycelium and/or gray spore masses (Fig. 2 A-D). Initial symptoms of Mucor rot were similar to those of blue mold, green mold, and sour rot. The diseased tissue was soft, watery, and the lesion developed a light- to dark-brown color. As the symptoms developed, white or gray shiny, erect sporangiophores started to develop from the lesions. At an advanced stage, the fruit was completely covered with masses of sporangiophores, on the top of which black or pale brown sporangia were evident (Fig. 2 E-H).

Because symptoms of the six major diseases at the early stage of disease development resembled each other, tissue isolations were still required to identify causal agents (Figs. 1 and 2). Although colony morphologies on PDA of the six major fungi were distinguishable from each other, selected isolates based on morphological identification of pathogens were confirmed by ITS sequence.
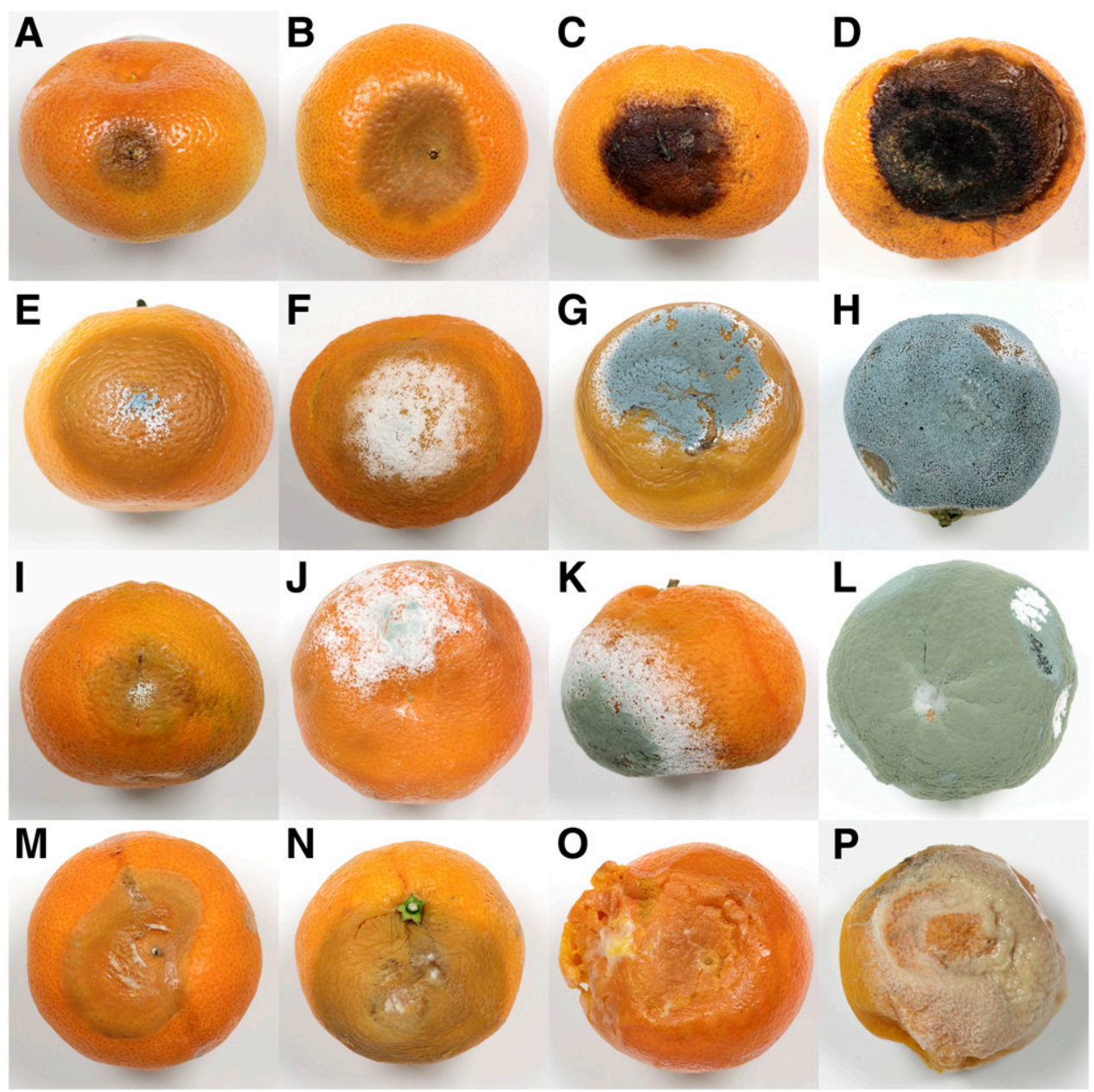

FIGURE 1

Symptoms of Alternaria rot (A to D), blue mold (E to $\mathbf{H})$, green mold (I to $\mathbf{L})$, and sour rot (M to $\mathbf{P})$ on mandarin fruit, caused by Alternaria spp., Penicillium italicum, $P$. digitatum, and Geotrichum spp., respectively. Pictures from left to right represent disease symptom development from an early stage to an advanced stage. 


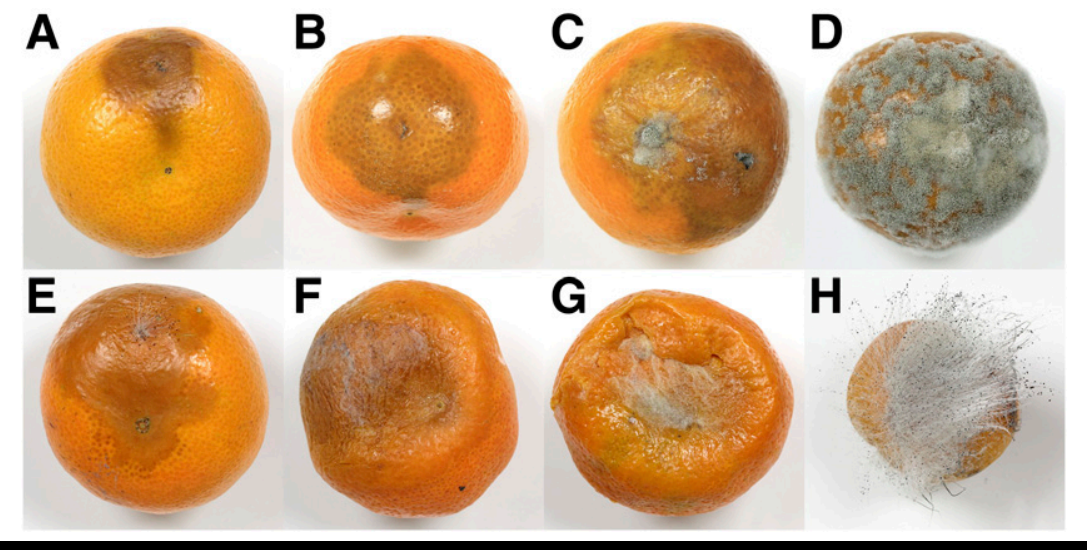

FIGURE 2

Symptoms of gray mold (A to $\mathbf{D})$ and Mucor rot (E to $\mathbf{H})$ on mandarin fruit caused by Botrytis spp. and Mucor spp., respectively. Pictures from left to right represent disease symptom development from an early stage to an advanced stage.

On the nonstored fruit, Alternaria rot was the most prevalent disease, accounting for $53.3 \%$ and $83.1 \%$ of the total decayed fruit collected in 2015 and 2016, respectively (Table 1). All grower lots had fruit infected by Alternaria spp. (Fig. 3). The percentage of Alternaria rot in the nonstored decayed fruit within a grower lot varied greatly from lot to lot in 2015 , from 14.4 to $84.4 \%$ with an average of $51.8 \%$, while all of the lots had higher levels of Alternaria rot in 2016, from 66.7 to $93.3 \%$ with an average of $83.1 \%$ (Fig. 3). The other major diseases, blue mold, green mold, sour rot, gray mold, and Mucor rot, commonly occurred on nonstored fruit but at a lower prevalence, from 6.2 to $16.5 \%$ and 2.1 to $6.5 \%$ in 2015 and 2016, respectively (Table 1). Percentage of the other five major diseases within a grower lot never exceeded more than $40 \%$ for both years (Fig. 3).

On the stored fruit, green mold was the most prevalent disease $(36.3 \%)$ in 2015 , followed by Mucor rot $(27.7 \%)$, blue mold $(23.3 \%)$, and sour rot $(17.2 \%)$, while gray mold was the most prevalent disease (29.7\%) in 2016, followed by Mucor rot (27.1\%), sour rot $(18.7 \%)$, and green mold (17.2\%) (Table 1). Compared with the nonstored fruit, the percentage of Alternaria rot on stored decayed fruit within a grower lot decreased, while that of the other five major diseases increased (Fig. 3). Percentage of blue mold, green mold, sour rot, gray mold, and Mucor rot in the total of decayed stored fruit within a grower lot varied greatly from lot to lot (Fig. 3).

The occurrence of green mold, blue mold, and sour rot on stored mandarin fruit was not unexpected as they are common postharvest diseases of citrus fruit in California and elsewhere (Brown and Eckert 2000b, 2000c, 2000d; Smilanick et al. 2008). Alternaria spp. can cause pre- and postharvest diseases on citrus fruit. Alternaria spp. affects navel oranges via infections of cracks at the navel or on the rind, causing a fruit rot that has been referred to as black rot. On lemons, Alternaria rot is most important as a stem-end rot on fruit that has been stored for an extended period of time in cold storage (Brown and Eckert 2000a). In the present study, Alternaria rot was most prevalent on the fruit that were collected at the presorting stage after harvest. The presence of Alternaria rot on these nonstored fruit indicates it was likely that symptoms of the disease had already developed on the fruit at harvest and pickers had inadvertently harvested these fruit. The lower prevalence of other diseases compared with Alternaria rot on the nonstored fruit may be explained by the lack of sufficient time for the pathogens to cause visible symptoms when examined at presorting. On stored fruit,
Alternaria rot also was present but with a much lower prevalence compared with that on the nonstored fruit, indicating that some infections by Alternaria spp. that had established on mandarin fruit in the field near harvest may have not developed visible symptoms on the fruit, but symptoms later developed after a period of time during storage.

In the present study, the isolates of Alternaria spp. obtained from mandarin fruit were small-spored Alternaria species. Black rot and brown spot on citrus were reportedly to be associated with various Alternaria species (Simmons 1999), among which A. alternata (Fr.) Keissler and A. citri Ellis \& Pierce have historically been considered two primary species (Snowdon 1990; Timmer et al. 2000). However, detailed phylogenetical analyses revealed that all citrus-associated Alternaria spp. in Florida were closely related but phylogenetically distinct lineages of A. alternata (Peever et al. 2004, 2005). In our work, although based on colony morphology and microscopic observations, different Alternaria spp. seemed to be associated with Alternaria rot on mandarin fruit. Identification of these Alternaria spp. isolates to species was beyond the scope of the present study. However, in view of high prevalence of Alternaria rot on nonstored fruit and its subsequent occurrence on stored fruit, a future study is needed to characterize Alternaria spp. associated with mandarin fruit and to facilitate the development of measures to control Alternaria rot before and after harvest.

\section{Mucor Rot and Gray Mold}

Although there was variability between the two years of collection, Mucor rot was the second most prevalent disease among stored fruit in both years (Table 1). Association of Mucor spp. with decayed citrus fruit was reported in the past (Akhtar et al. 2013; Bukar et al. 2009); however, the species identification and pathogenicity were not studied in these reports. In our previous study, 197 Mucor spp. isolates collected from citrus packinghouses in 2015 were identified based on genetic and morphological characteristics; and five Mucor species-M. circinelloides, M. hiemalis, $M$. mucedo, $M$. racemosus, $M$. piriformis-were found to be associated with Mucor rot on mandarin fruit with $M$. piriformis being the most virulent and most prevalent species, accounting for $92.4 \%$ (Saito et al. 2016). Thus, control of Mucor rot at citrus packinghouses should target this species.

Although the increase in the prevalence of gray mold among stored fruit in 2016 may be attributed to the relatively high precipitation during the 2015-2016 harvest season (during late fall to 
Non-stored fruit
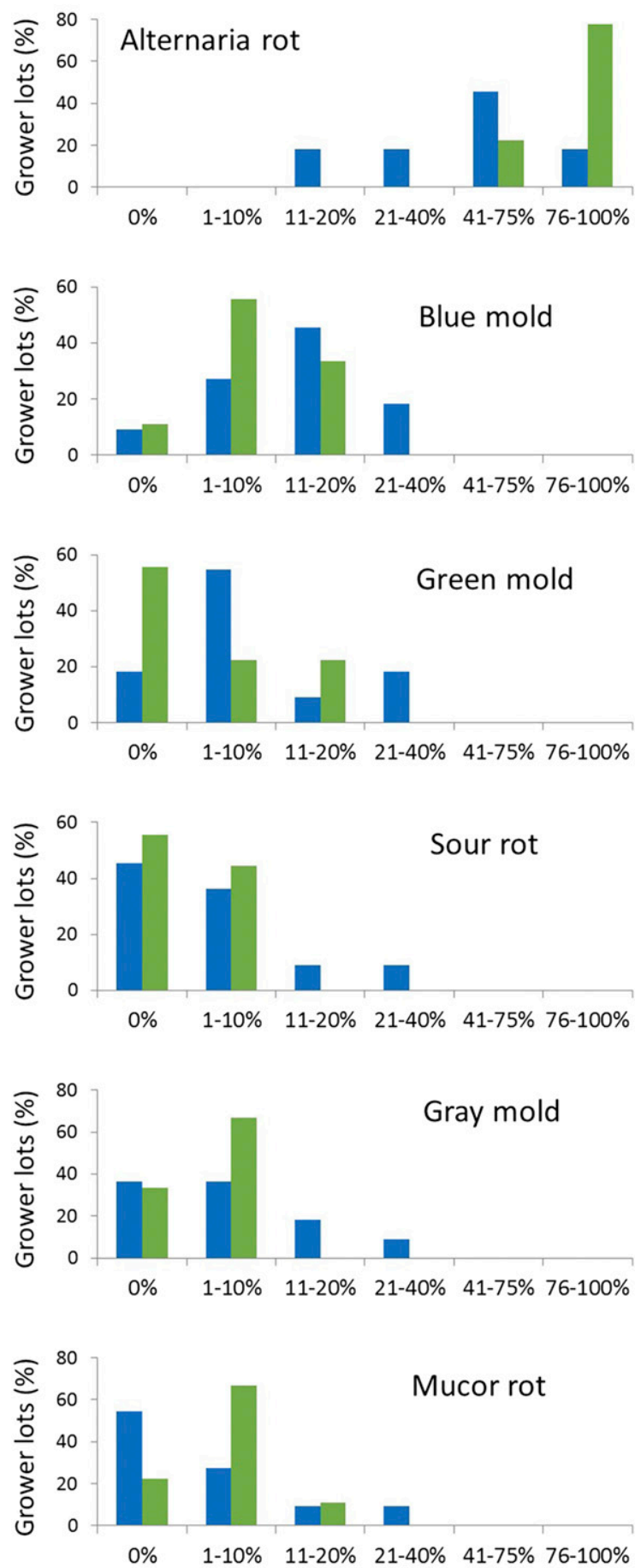

Stored fruit
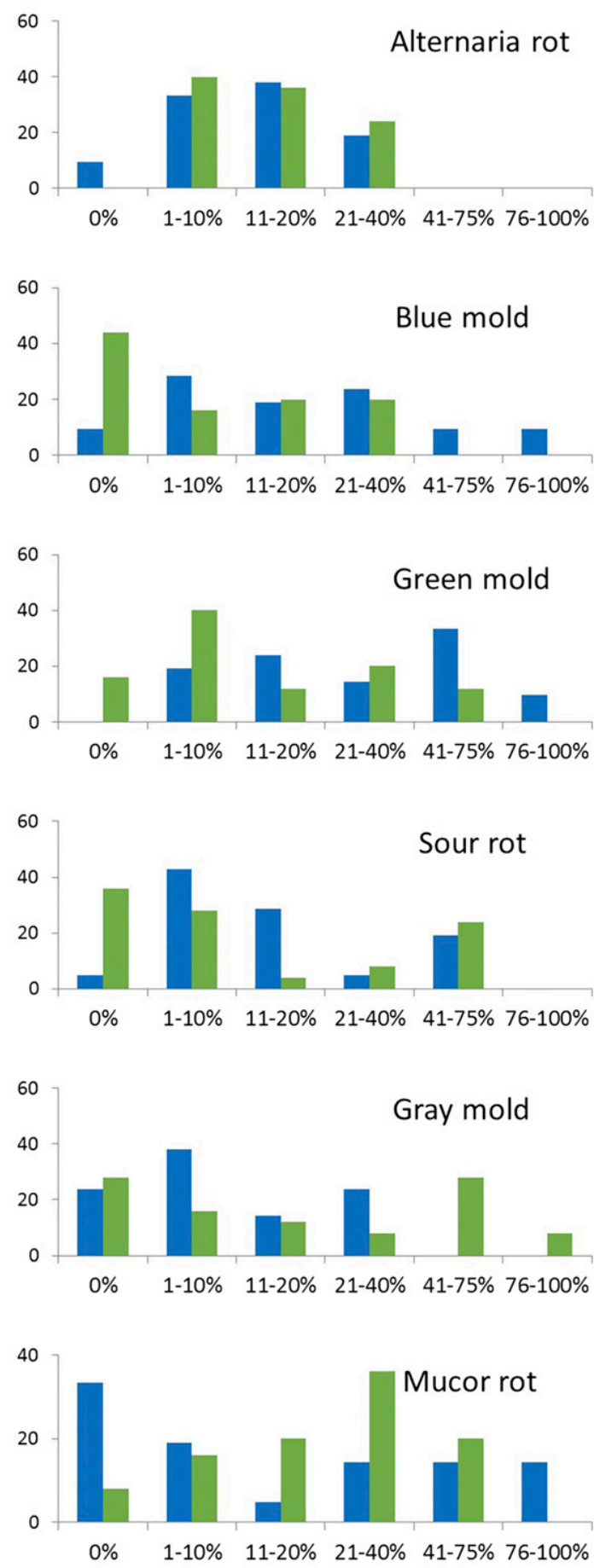

Percentage of the total decayed fruit within a grower lot

FIGURE 3

Percentage of grower lots showing Alternaria rot, blue mold, green mold, sour rot, gray mold, and Mucor rot expressed as percentages of the total decayed mandarin fruit within a grower lot for the nonstored fruit and stored fruit. Blue and green columns represent the years 2015 and 2016 , respectively. In 2015 and 2016, respectively, eleven and nine grower lots for the nonstored fruit and 21 and 25 grower lots for the stored fruit were examined.

winter), it is noteworthy that gray mold was the most prevalent disease in that year. Although management of important citrus postharvest diseases has been studied, Mucor rot and gray mold have never been included in those previous studies (Arpaia et al. 2014; Smilanick et al. 2006, 2008). Since these two diseases appeared to be emerging postharvest diseases on mandarin fruit resulting from the recent changes in postharvest handling practices, Mucor rot and gray mold need to be included among diseases targeted in postharvest disease control programs for mandarins in California. Our current research efforts focus on the development of 
TABLE 2

Percentages of decayed fruit originating from infections at different sites on the fruit for each individual disease

\begin{tabular}{|c|c|c|c|c|c|}
\hline \multirow[b]{2}{*}{ Disease } & \multirow[b]{2}{*}{ Site } & \multicolumn{2}{|c|}{2015} & \multicolumn{2}{|c|}{2016} \\
\hline & & Nonstored fruit & Stored fruit & Nonstored fruit & Stored fruit \\
\hline \multirow[t]{4}{*}{ Alternaria rot } & Stem-end & 0.9 & 7.9 & 1.1 & 1.4 \\
\hline & Stylar-end & 17.6 & 15.8 & 28.1 & 23.0 \\
\hline & Unknown & 2.2 & 2.6 & 7.9 & 5.4 \\
\hline & Number of fruit & $(227)^{\mathrm{a}}$ & (38) & (267) & (74) \\
\hline \multirow{3}{*}{ Blue mold } & Stylar-end & 4.3 & 0 & 5.0 & 0 \\
\hline & Unknown & 14.9 & 28.6 & 5.0 & 43.8 \\
\hline & Number of fruit & (47) & (49) & (20) & (32) \\
\hline \multirow[t]{3}{*}{ Green mold } & Stem-end & 6.3 & 0 & 0 & 0 \\
\hline & rind & 93.8 & 46.1 & 83.3 & 30.9 \\
\hline & Stylar-end & 0 & 0 & 0 & 0 \\
\hline \multirow{3}{*}{ Sour rot } & Stylar-end & 0 & 2.6 & 0 & 1.9 \\
\hline & Unknown & 0 & 9.2 & 0 & 28.3 \\
\hline & Number of fruit & (16) & (76) & (2) & (53) \\
\hline \multirow[t]{5}{*}{ Gray mold } & Stem-end & 3.8 & 5.0 & 0 & 0 \\
\hline & rind & 96.2 & 75.0 & 100 & 34.4 \\
\hline & Stylar-end & 0 & 0 & 0 & 0 \\
\hline & Unknown & 0 & 20.0 & 0 & 65.6 \\
\hline & Number of fruit & (26) & (40) & (5) & (189) \\
\hline \multirow[t]{4}{*}{ Mucor rot } & Stem-end & 0 & 0 & 0 & 0 \\
\hline & rind & 84.2 & 65.5 & 100 & 31.8 \\
\hline & Stylar-end & 5.3 & 0.7 & 0 & 0 \\
\hline & Unknown & 10.5 & 33.8 & 0 & 68.2 \\
\hline
\end{tabular}

${ }^{a}$ Numbers in the parenthesis are the number of fruit infected by respective single pathogen, and decayed fruit with multipathogen infection were excluded.

postharvest measures to control these two diseases in addition to other common target diseases such as green mold and sour rot.

\section{Infection Sites}

For each decayed fruit, the infection site was recorded as follows: infection starts from the stem end, referred to as "stem-end rot"; infection starts from the stylar end, referred to as "stylar-end rot"; and infection starts from neither the stem end nor stylar end, referred to as "rind rot". In some cases it was difficult to identify infection sites on the fruit that were completely rotted, and were referring to as "unknown". Regardless of type of diseases, the vast majority of decayed fruit originated from wound infections on the fruit rind (Table 2). Alternaria rot has been reported to occur primarily as a stem-end rot in citrus types other than mandarin fruit (Brown and Eckert 2000a). However, our results suggested that Alternaria rot was more likely associated with a stylar-end rot than a stem-end rot on mandarin fruit (Table 2). There were more completely decayed fruit (entire fruit decayed) among the stored fruit than nonstored fruit, thus the increased percentage of those classified as "unknown" for infection site among the stored fruit (Table 2). These findings indicated that most infections occurred through fruit injures created during harvesting and subsequent handling rather than from latent infections initiated before harvest through the stem end or stylar end.

In summary, this is the first report on the prevalence and incidence of postharvest diseases of stored mandarin fruit in
California. We found that six major postharvest diseases commonly occurred in mandarin fruit in California. In addition to green and blue mold and sour rot, which are common postharvest diseases affecting citrus fruit, Mucor rot and gray mold are two emerging postharvest diseases on stored mandarin fruit. Because storing mandarin fruit has become a common practice in the California citrus industry, our survey results indicate that to minimize postharvest losses of stored mandarin fruit, postharvest disease control programs for mandarin fruit should target not only green and blue mold and sour rot but also Mucor rot and gray mold.

\section{Acknowledgments}

This research was supported in part by the California Citrus Research Board. We thank J. L. Smilanick, and K. Fjeld for technical assistance and the personnel of the three citrus packinghouses for assistance in sample collection.

\section{Literature Cited}

Akhtar, N., Anjum, T., and Jabeen, R. 2013. Isolation and identification of storage fungi from citrus sampled from major growing areas of Punjab, Pakistan. Int. J. Agric. Biol. 15:1283-1288.

Arpaia, M. L., Adaskaveg, J. E., Smilanick, J., and Elliot, R. 2014. Postharvest handling. Pages 369-382 in: Citrus Production Manual. L. Ferguson and E. E. Grafton-Cardwell, eds. Agric. and Nat. Res. Pub. 3539, Univ. of Calif., Oakland, CA. 
Barnett, H. L., and Hunter, B. B. 1998. Illustrated Genera of Imperfect Fungi, 4th Ed. American Phytopathological Society, St. Paul, MN.

Bhattarai, R. R., Rijal, R. K., and Mishra, P. 2013. Post-harvest losses in mandarin orange: A case study of Dhankuta district. Nepal. Afr. J. Agric. Res. 8:763-767.

Brown, G. E., and Eckert, J. W. 2000a. Alternaria rot. Page 37 in: Compendium of Citrus Diseases, 2nd Ed. L. W. Timmer, S. M. Garnsey, and J. H. Graham, eds. American Phytopathological Society, St. Paul, MN.

Brown, G. E., and Eckert, J. W. 2000b. Blue mold. Page 41 in: Compendium of Citrus Diseases, 2nd Ed. L. W. Timmer, S. M. Garnsey, and J. H. Graham, eds. American Phytopathological Society, St. Paul, MN.

Brown, G. E., and Eckert, J. W. 2000c. Green mold. Pages 41-42 in: Compendium of Citrus Diseases, 2nd Ed. L. W. Timmer, S. M. Garnsey, and J. H. Graham, eds. American Phytopathological Society, St. Paul, MN.

Brown, G. E., and Eckert, J. W. 2000d. Sour rot. Page 43 in: Compendium of Citrus Diseases, 2nd Ed. L. W. Timmer, S. M. Garnsey, and J. H. Graham, eds. American Phytopathological Society, St. Paul, MN.

Bukar, A., Mukhatar, M. D., and Adamu, S. 2009. Isolation and identification of postharvest spoilage fungi associated with sweet oranges traded in Kano metropolis. Bayero J. Pure Appl. Sci. 2:122-124.

Hall, T. A. 1999. BioEdit: A user-friendly biological sequence alignment editor and analysis program for Windows 95/98/NT. Nucl. Acids. Symp. Ser. 41: 95-98.

Kim, Y. K., and Xiao, C. L. 2008. Distribution and incidence of Sphaeropsis rot in apple in Washington State. Plant Dis. 92:940-946.

Ladaniya, M. 2008. Citrus Fruit: Biology, Technology and Evaluation. Academic Press, San Diego, CA

McKay, A. H., Förster, H., and Adaskaveg, J. E. 2012. Efficacy and application strategies for propiconazole as a new postharvest fungicide for managing sour rot and green mold of citrus fruit. Plant Dis. 96:235-242.

Peever, T. L., Carpenter-Boggs, L., Timmer, L. W., Carris, L. M., and Bhatia, A. 2005. Citrus black rot is caused by phylogenetically distinct lineages of Alternaria alternata. Phytopathology 95:512-518.

Peever, T. L., Su, G., Carpenter-Boggs, L., and Timmer, L. W. 2004. Molecular systematics of citrus-associated Alternaria species. Mycologia 96:119-134.

Saito, S., Michailides, T. J., and Xiao, C. L. 2016. Mucro rot-An emerging postharvest disease of mandarin fruit caused by Mucor piriformis and other Mucor spp. in California. Plant Dis. 100:1054-1063.
Samson, R. A., and Pitt, J. I. 2000. Integration of Modern Taxonomic Methods for Penicillium and Aspergillus Classification. Harwood, Amsterdam, The Netherlands.

Schipper, M. A. A. 1973. A study on variability in Mucor hiemalis and related species. Stud. Mycol. 4:1-40.

Schipper, M. A. A. 1975. On Mucor mucedo, Mucor flavus and related species. Stud. Mycol. 10:1-33.

Schipper, M. A. A. 1976. On Mucor circinelloides, Mucor racemosus and related species. Stud. Mycol. 12:1-40.

Schipper, M. A. A. 1978. On certain species of Mucor with a key to all accepted species. Stud. Mycol. 17:53-71.

Simmons, E. G. 1999. Alternaria themes and variations (226-235) Classification of citrus pathogens. Mycotaxon 70:263-323.

Simmons, E. G. 2007. Alternaria: An Identification Manual. CBS Biodiversity Series 6. CBS Fungal Biodiversity Centre, Utrecht, The Netherlands.

Smilanick, J. L., Mansour, M. F., Gabler, F. M., and Soreson, D. 2008. Control of citrus postharvest green mold and sour rot by potassium sorbate combined with heat and fungicides. Postharvest Biol. Technol. 47:226-238.

Smilanick, J. L., Mansour, M. F., and Sorenson, D. 2006. Pre- and postharvest treatments to control green mold of citrus fruit during ethylene degreening. Plant Dis. 90:89-96.

Snowdon, A. L. 1990. Citrus fruits. Pages 54-91 in: A Color Atlas of PostHarvest Diseases and Disorders of Fruits and Vegetables, Vol. 1. CRC Press, Boca Raton, FL.

Timmer, L. W., Solel, Z., and Orozco-Santos, M. 2000. Alternaria Brown Spot of Mandarins. Pages 19-20 in: Compendium of Citrus Diseases, 2nd Ed. L. W. Timmer, S. M. Garnsey, and J. H. Graham, eds. American Phytopathological Society, St. Paul, MN.

Webber, H. J., Barker, R., and Ferguson, L. 2014. History and Development of the California Citrus Industry. Pages 3-20 in: Citrus Production Manual. L. Ferguson and E. E. Grafton-Cardwell, eds. Agric. and Nat. Resources Publ. 3539, Univ. of Calif., Oakland, CA.

White, T. J., Bruns, T., Lee, S., and Taylor, J. 1990. Amplification and direct sequencing of fungal ribosomal RNA genes for phylogetetics. Pages 315-322 in: PCR Protocols: A Guide to Methods and Applications. M. A. Inis, D. H. Gelfand, J. J. Sninsky, and T. J. White, eds. Academic Press, New York. 